\title{
Expression and Antibody Inhibition of P-Type Calcium Channels in Human Small-Cell Lung Carcinoma Cells
}

\author{
Elizabeth L. R. Barry, ${ }^{1}$ Michael P. Viglione, ${ }^{2}$ Yong I. Kim, ${ }^{3}$ and Stanley C. Froehner ${ }^{4}$ \\ 'Department of Pharmacology and Toxicology, Dartmouth Medical School, Hanover, New Hampshire 03755, ${ }^{2}$ Program in \\ Neuroscience and ${ }^{3}$ Departments of Biomedical Engineering and Neurology, University of Virginia, Charlottesville, Virginia \\ 22908, and ${ }^{4}$ Department of Physiology, University of North Carolina, Chapel Hill, North Carolina 27599
}

\begin{abstract}
P-type channels, a recently described form of voltage-gated calcium channels, are found in many central and peripheral neurons. In the present study, a partial cDNA clone sharing extensive nucleotide identity with a putative P-type voltagegated calcium channel $\alpha_{1}$ subunit was isolated from a smallcell lung carcinoma (SCLC) cell line. Anti-peptide antibodies generated to a unique acidic stretch in the IVS5-S6 linker region of the putative SCLC P-type channel reacted specifically with a SCLC fusion protein produced in bacteria and with a cell surface molecule in SCLC cells. Calcium currents in SCLC cells, measured by whole-cell patch clamp, were inhibited by these antibodies and by the P-type channelspecific toxin $\omega$-agatoxin IVA. The inhibitory effects of the antibody and the toxin were not additive, consistent with their proposed action on the same type of channel. These results provide evidence for the expression of P-type calcium channels by SCLC cells. The expression of neuronrelated molecules by these cells is of particular interest because small-cell lung carcinoma is frequently associated with paraneoplastic disorders affecting the nervous system.

IKey words: calcium channel cDNA, P-type calcium channel, human small-cell lung carcinoma, polyclonal antibody, $\omega$-agatoxin IVA, patch clampJ
\end{abstract}

Small-cell lung carcinoma (SCLC) is a common form of lung cancer in which the tumor cells express neuroendocrine-like properties. SCLC is frequently associated with paraneoplastic disorders affecting the nervous system. Of particular interest is the Lambert-Eaton myasthenic syndrome (LES), an autoimmune disease of neuromuscular transmission that is often associated with SCLC (Lang et al., 1983; Kim, 1986; Vincent et al., 1989). The target of the autoimmune reaction is thought to be a voltage-gated calcium channel in the presynaptic membrane that couples neurotransmitter release to membrane depolarization (Kim and Neher, 1988; Peers et al., 1990). Autoantibody production may be triggered by the expression of a voltage-

\footnotetext{
Received Oct. 1, 1993; revised May 20, 1994; accepted June 16, 1994.

We thank Dr. Michael E. Adams for his generous gift of $\omega$-agatoxin IVA and Tom O'Shaughnessy for his help with initial experiments on the effect of the antipeptide antibodies on $I_{\mathrm{ta}}$. This work was supported by a Muscular Dystrophy Association Fellowship to E.L.R.B. for work performed in the lab of S.C.F. while in the Department of Biochemistry at Dartmouth Medical School. Additional support was from NIH Grant NS27504 to S.C.F. and NS18607 to Y.I.K, and a research grant from the Muscular Dystrophy Association to Y.I.K.

Correspondence should be addressed to Dr. Stanley C. Froehner, Department of Physiology, CB 7545, University of North Carolina, Chapel Hill, NC 27599.

Copyright (C) 1995 Society for Neuroscience 0270-6474/95/150274-10\$05.00/0
}

gated calcium channel in SCLC cells that resembles that found at the presynaptic nerve terminal (Roberts et al., 1985).

Voltage-gated calcium channels (VGCCs) regulate calcium influx into neuronal cells and control the calcium-dependent release of neurotransmitters and peptide hormones (Miller, 1987). It is likely that VGCCs play a similar role in SCLC cells, which are known to secrete a large number of ectopic hormones (Russell et al., 1990). VGCCs are generally classified as L-, N-, P-, and $\mathrm{T}$-type based on their electrophysiological behavior and distinct pharmacological sensitivities. Although P-type channels were originally described in Purkinje cells (Llinás et al., 1992), hence the name, there is now evidence for a wider distribution in the nervous system (Llinás et al., 1989; Hillman et al., 1991; Regan et al., 1991; Usowicz et al., 1992). P-type channels are resistant to both dihydropyridine (DHP) antagonists and $\omega$-conotoxin GVIA ( $\omega$-CgTx-GVIA), but are blocked by toxins isolated from venom of the funnel web spider. These toxins include a small polyamine toxin, funnel toxin (FTX) (I linás et al., 1989, 1992), and a peptide toxin, $\omega$-agatoxin IVA ( $\omega$-Aga-IVA) (Mintz et al., 1992a,b). The release of the neurotransmitter glutamate at mammalian presynaptic nerve terminals is blocked by $\omega$-AgaIVA, implicating P-type channels (Turner et al., 1992). Furthermore, the mammalian neuromuscular junction contains P-type channels as indicated by the inhibition of presynaptic calcium flux by FTX (Uchitel et al., 1992). The evoked release of acetylcholine at the mammalian neuromuscular junction is likewise blocked by FTX (Uchitel et al., 1992) and $\omega$-Aga-IVA (Kim et al., 1993). Finally, P-type channels are sensitive to a novel conotoxin, $\omega$-CgTx-MVIIC, that acts on mammalian presynaptic nerve terminals (Hillyard et al., 1992).

The $\alpha_{1}$ subunit of VGCCs forms the pore of the channel and is cvolutionarily related to voltagc-gated $\mathrm{Na}^{+}$and $\mathrm{K}+$ channels. Six classes of calcium channel $\alpha_{1}$ subunits have now been identified by molecular cloning (Snutch and Reiner, 1992). Three of these classes are believed to be L-type channels, including those isolated from skeletal and cardiac muscle and brain (Tanabe et al., 1987; Mikami et al., 1989; Hui et al., 1991). A fourth class includes a presumptive P-type $\alpha$, subunit, called B 1, which was isolated from rabbit brain and expressed in Xenopus oocytes (Mori et al., 1991). It resembles P-type channels in its apparent tissue distribution; however, its single-channel properties and pharmacology are not entirely consistent with that of P-type channels described in Purkinje cells (Sather et al., 1993). A fifth class of $\alpha_{1}$ subunits is sensitive to $\omega$-CgTx-GVIA and therefore corresponds to N-type channels (Dubel et al., 1992; Williams et al., 1992). Finally, the most recently described class has characteristics of a low-voltage-activated (T-type) calcium channel 
(Soong et al., 1993). The functional properties of another recently cloned calcium channel have not yet been described (Niidome et al., 1992), but the channel appears to be most closely related to a calcium channel isolated from a marine ray that expresses novel kinetic and pharmacological characteristics (Ellinor et al., 1993).

There is considerable evidence that SCLC cells express voltage-gated calcium channels. Depolarization-induced $\mathrm{Ca}^{2+} \mathrm{flux}$ in SCLC cells is inhibited by DHP antagonists and $\omega$-CgTxGVIA, thereby suggesting the presence of L- and N-type channels (De Aizpurua et al., 1988; Sher et al., 1990). In addition, the whole-cell patch-clamp technique has been used to demonstrate the presence of DHP-sensitive L-type channels (Pancrazio et al., 1989; Pancrazio et al., 1992). In the present study we identify a presumptive P-type VGCC transcript in SCLC cells. A polyclonal antiserum was produced to a peptide encoded by a partial cDNA clone. The purified antibodies inhibited calcium currents expressed in SCLC cells, as did the P-type channel-specific toxin $\omega$-Aga-IVA. These results provide evidence for the expression of a P-type calcium channel in SCLC cells.

\section{Materials and Methods}

\section{Cell culture}

$\mathrm{H} 146, \mathrm{H} 209$, and $\mathrm{H} 345$ human small-cell lung carcinoma cells (Gazdar et al., 1980) were obtained from American Type Culture Collection and cultured in RPMI 1640 medium (GIBCO/Bethesda Research Labs) supplemented with 10\% fetal bovine serum (GIBCO/Bethesda Research Labs). H146 cells were chosen as the experimental model due to their robust calcium currents (Pancrazio et al., 1989); normal untreated H146 cells demonstrate maximal $I_{\mathrm{Ca}}$ ranging from $10 \mathrm{pA}$ to $375 \mathrm{pA}$ [mean of $115.8 \pm 3.9( \pm$ SEM) pA, $n=303$ cells]. The $\mathrm{C} 2$ mouse muscle cell line was cultured as described (Silberstein et al., 1982) and fused myotubes were used for the isolation of RNA.

\section{Isolation of $c D N A$ clones by $P C R$}

Purification of $R N A$. PolyA ${ }^{+}$RNA was isolated from cultured cells as previously described (Bradley et al., 1988). Briefly, cells were pelleted by centrifugation and homogenized in the presence of $2 \%$ SDS. After incubation with proteinase $\mathrm{K}$ (Boehringer Mannheim), the cell lysate was batch adsorbed to oligo(dT) cellulose (Collaborative Research), and polyA ${ }^{+}$RNA was eluted in salt-free buffer.

First-strand $c D N A$ synthesis. PolyA ${ }^{+}$RNA, $10 \mu \mathrm{g}$, was reverse transcribed in a $100 \mu \mathrm{l}$ reaction volume containing $10 \mathrm{U} / \mu \mathrm{l}$ Moloney murine leukemia viral reverse transcriptase (GIBCO/Bethesda Research Labs), $10 \mathrm{ng} / \mu \mathrm{l}$ random hexamers (Pharmacia), $0.5 \mathrm{~mm}$ dNTPs (Pharmacia), $100 \mu \mathrm{g} / \mathrm{ml}$ bovine serum albumin (GIBCO/Bethesda Rescarch Labs), and $1 \mathrm{U} / \mu \mathrm{l}$ RNasin (Promega) in $50 \mathrm{~mm}$ Tris- $\mathrm{HCl}, \mathrm{pH} 8.3,75 \mathrm{~mm} \mathrm{KCl}$, $10 \mathrm{~mm}$ dithiothreitol (DTT), and $3 \mathrm{~mm} \mathrm{MgCl}$. The mixture was incubated for $5 \mathrm{~min}$ at room temperature (to extend the hexamers) followed by $1 \mathrm{hr}$ at $37^{\circ} \mathrm{C}$. The cDNA product was isolated by phenol: chloroform extraction and ethanol precipitation for use in PCR.

$P C R$. Aliquots of CDNA, equivalent to $1 / 10$ of the above reaction, were incubated in a $100 \mu \mathrm{l}$ reaction volume containing $10 \mathrm{~mm}$ Tris$\mathrm{HCl}, \mathrm{pH} 8.3,50 \mathrm{~mm} \mathrm{KCl}, 1.5 \mathrm{~mm} \mathrm{MgCl}, 0.001 \%$ gelatin, $200 \mu \mathrm{M}$ of each dNTP, $0.2 \mu \mathrm{M}$ of each primer, and $2.5 \mathrm{U}$ of DNA polymerase (amplitaq, Perkin-Elmer), and overlaid with $100 \mu \mathrm{l}$ of mineral oil (Sigma). PCR was performed on an automated thermalcycler (Perkin-Elmer Cetus) that was programmed to repeat the following cycle 30 times: 60 $\mathrm{sec}$ at $94^{\circ} \mathrm{C}, 60 \mathrm{sec}$ at $60^{\circ} \mathrm{C}$, and then $120+2 \mathrm{sec} / \mathrm{cycle}$ at $72^{\circ} \mathrm{C}$.

PCR primers. Primers wcre designed from regions that are perfectly conserved between rabbit skeletal (Tanabe et al., 1987) and cardiac muscle (Mikami et al., 1989) L-type calcium channels. The sequence of the upstream primer was $5^{\prime}$-gtgggaattcatcaagtccttccaggcct-3', and the downstream primer, 5'-caggggatccaagttgtccatgatgacagc-3'. Restriction sites (italic) were included near the $5^{\prime}$ ends of the primers to facilitate directional subcloning: EcoR 1 in the upstream primer and BamHl in the downstream primer. The PCR primers were synthesized locally and crude trityl-on oligonucleotides were eluted from the glass support columns with ammonium hydroxide and purified on Nensorb (Dupont) prep columns.
Cloning. The products of the PCR reaction were directionally cloned into the Bluescript KS vector (Stratagene). Initially, one-fifth of each PCR reaction was analyzed by electrophoresis on $3 \%$ Nuseive/ $1 \%$ Seakem agarose (FMC) gels. For subcloning, the remaining reaction product was purified by phenol extraction and ethanol precipitation, digested with EcoR1 and BamH1, and isolated as a band from a low-melt Nuseive/agarose gel. The vector was also digested with EcoR 1 and BamH1 and isolated on a low-melt agarose gel. The PCR product and vector were ligated and used to transform XL-1 Blue bacteria. Plasmid DNA was prepared from individual colonies and sequenced by the dideoxynucleotide chain termination procedure from double-stranded DNA templates. Sequence comparison was performed using the Intelligenetics and the Genetics Computer Group on-line software.

\section{Northern blot analysis}

Total RNA was isolated from cultured cells by the guanidinium isothiocyanate/phenol procedure (Chomczynski and Sacchi, 1987). Total RNA, $50 \mu \mathrm{g}$, was run in each lane of an $0.8 \%$ agarose-formaldehyde denaturing gel and electrophoretically transferred to Genescreen nylon membrane (Dupont). The membranes were UV cross-linked and then prehybridized in $0.75 \mathrm{M} \mathrm{NaCl}, 0.05 \mathrm{M} \mathrm{NaH}_{2} \mathrm{PO}_{4}, 5 \mathrm{~mm}$ EDTA, $0.1 \%$ Ficoll, $0.1 \%$ polyvinylpyrrolidone, $0.1 \%$ bovine serum albumin (BSA) (Pentax Fraction V), 50\% formamide, $1 \%$ SDS, $10 \%$ dextran sulfate, and $100 \mu \mathrm{g} / \mathrm{ml}$ salmon sperm DNA at $45^{\circ} \mathrm{C}$ for $20 \mathrm{hr}$. Hybridization with ${ }^{32} \mathbf{P}$-labeled riboprobes was carried out under the same conditions as the prehybridization. The membranes were then washed in $15 \mathrm{~mm}$ $\mathrm{NaCl}, 1 \mathrm{~mm} \mathrm{NaH} \mathrm{PO}_{4}, 0.1 \mathrm{~mm}$ EDTA, and $0.1 \%$ SDS at $65^{\circ} \mathrm{C}$ and treated with $1 \mu \mathrm{g} / \mathrm{ml} \mathrm{RNase} A$ for $15 \mathrm{~min}$ in $0.3 \mathrm{M} \mathrm{NaCl}$ and $30 \mathrm{~mm}$ $\mathrm{Na}_{3}$ citrate to decrease background interference. Autoradiography was carried out at $-70^{\circ} \mathrm{C}$ with an intensifying screen. Hybridization with a control riboprobe for human $\beta$-actin was used to demonstrate that similar amounts of undegraded RNA were probed in each lane (not shown).

\section{Production and characterization of polyclonal antibodies}

Peptide design and antibody isolation. A peptide, $\mathrm{NH}_{2}$-IDVEDEDSDEDEFC- $\mathrm{CO}_{2}$, corresponding to a unique nucleotide stretch (residues 79-118) in clone SCLC-P, was synthesized, conjugated to keyhole limpet hemocyanin, and used for the production of antiserum in rabbits (Macromolecular Resources, Fort Collins, CO). Peptide-specific antibody was purified by affinity chromatography. Peptide, $25 \mathrm{mg}$, was solubilized in DMSO and coupled to $2 \mathrm{ml}$ of Aff Gel-10 resin (Bio-Rad). Antiserum was heat inactivated and batch absorbed to peptide resin equilibrated in $137 \mathrm{~mm} \mathrm{NaCl}, 2.7 \mathrm{mM} \mathrm{KCl}, 4.3 \mathrm{mM} \mathrm{Na}_{2} \mathrm{HPO}_{4}$, and $1.4 \mathrm{mM} \mathrm{KH}_{2} \mathrm{PO}_{4}$ (PBS). Antibody was eluted in $0.2 \mathrm{M}$ glycine, $\mathrm{pH} 2.5$, immediately neutralized with $1.5 \mathrm{M}$ Tris, $\mathrm{pH} 8.8$, and dialyzed against PBS. The affinitypurified antibody was used for Western blotting and immunofluorescence and in patch-clamp experiments.

Subcloning the SCLC-P clone into a bacterial expression vector. The SCLC-P clone was subcloned into the BamHI site of the bacterial expression vector pGEX-3X (Pharmacia) as follows. SCLC-P cDNA generated by PCR was restriction digested at the $3^{\prime}$ end with Mbol at nucleotide 17 , generating sticky ends that are compatible with those generated by $\mathrm{BamH} 1$, and at the $5^{\prime}$ end with BamH1 at the site engineered into the PCR primer. The restricted SCLC-P DNA was ligated to the BamH1-digested vector and the products were used to transform XL-1 Blue bacteria. Recombinants containing the SCLC-P insert in the sense orientation were selected by restriction analysis and used for the expression of a fusion protein.

Expression of the SCLC-P fusion protein. Transformed bacteria containing either the SCLC-P recombinant vector or control vector (without insert) were grown overnight at $37^{\circ} \mathrm{C}$ in LB medium containing ampicillin. Cultures were diluted 1:10 in fresh medium and grown for $1 \mathrm{hr}$ before expression of the glutathione- $S$-transferase (GST) fusion protein was induced by the addition of IPTG, $0.1 \mathrm{~mm}$ final concentration. After $5 \mathrm{hr}$, the cells were harvested by centrifugation and solubilized in gel sample buffer $(0.125 \mathrm{~m}$ Tris- $\mathrm{HCl}, \mathrm{pH} 7.4,4 \% \mathrm{SDS}, 200 \mathrm{~mm}$ DTT, $20 \%$ glycerol, bromphenol blue). Total cell lysates were analyzed by electrophoresis on $12 \%$ SDS-PAGE gels. Some lanes of the gel were cut out for visualization of protein by staining with Coomassie brilliant blue. Duplicate lanes from the gel were electrophoretically transferred to nitrocellulose paper for Western blotting.

Western blotting. Duplicate nitrocellulose strips were incubated in 10 mм Tris- $\mathrm{HCl}, \mathrm{pH} 7.4,500 \mathrm{~mm} \mathrm{NaCl}, 0.05 \%$ Tween- $20,0.1 \%$ cold water fish gelatin, $0.08 \% \mathrm{BSA}$, and $6 \%$ normal goat serum at room temperature 
GCTTATGTCTGTCTGCTGATCGCCATGCTCTTCTTCATCI

A HumSCLC-P

RabBrain-P

5497

201

5597

301

5697

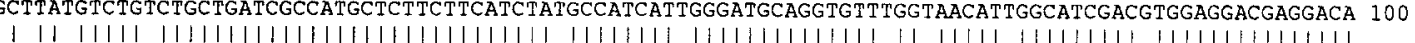
CCCTACGTCTGCCTGCTGATCGCCATGCTCTPCPTCATCTACGCCATCATCGGGATGCAGGTGTTCGGCAACATCGGCATCGACATGGAGGACGAGGACA 5496

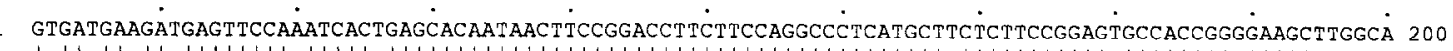

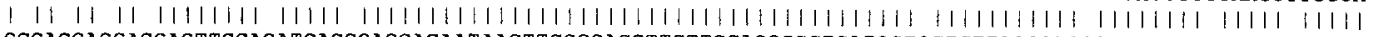

97 GCGACGAGGACGAGTTCCAGATCACCGAGCACAATAACTTCCGGACCTTCTTCCAGGCCCTCATGCTGCTCTTCCGGAGCGCCACCGGAGAAGCCTGGCA 5596

1 CAACATCATGCTTTCCTGCCTCAGCGgGAAACCGTGTGATAAGAACTCTGGCATCCTGACTCGAGAGTGTGGCAATGAATTGCTTATTTTTACTTTGTT 300

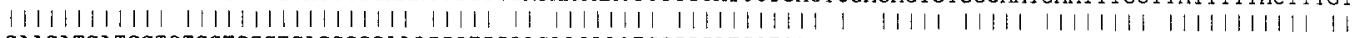
CAACATCATGCTGTCCTGCCTCAGCGGGAGCCGTGCGACAAGAACTCGGGCATCCTGACGCCTGAGTGCGGCAACGAATTIGCCTATTTTTACTTCGTG 5646 IVS 6 TCCTTCATCTTCCTCTGCTCGTTTCTGATGCTGAATCTCTTTGTC 345 |||||||||||||||||||| || |||||| |||| |||||||| TCCTTCATCTTCCTCTGCTCCTTCCTGATGTTGAACTCTTTGTG 5741

B 1 IVS 5

RabBrain-P WAMLF I YAI IGMQVEGN IGIDVEDEDSDEDEEQITEHNNERTEFQALMLLFRSATGEAWHN IMLSCLSGKPCDKNSG ILTRECGNEFAYFYFVSF IFLCSFLMLNLEV

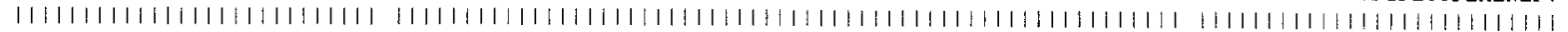
PYVCLL I AMLFF I YAI IGMOVFGN IG IDMEDED DEDEFQI TEHNNERTFFQALMLLERSATGEAWHN IMLSCLSCKPCDKNSGI LTPECGNEF AYFYFVSF IFLCSF LMLNLFV 1702 . 18.9.

C HumSCLC-P RabBrainRabBrain-P HumBrain-N RatBrain-T RabCardiac RatBrain-L

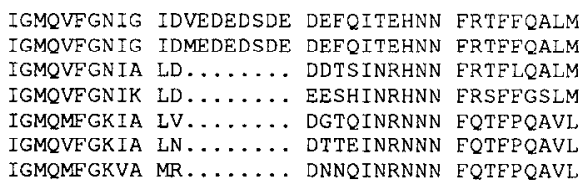

Figure 1. Scquence of SCLC-P Ca'+ channel $\alpha_{1}$ subunit CDNA clone. The nucleotide sequence $(A)$ and the deduced amino acid sequence $(B)$ of the SCLC-P clone (HumSCLC-P) are compared with the rabbit brain (P-type) $\mathrm{Ca}^{2+}$ channel sequence (RabBrain-P) (Mori et al., 1991). Residues that are identical are connected by dashes. The numbers at ends of each line are the nucleotide or amino acid residue numbers. The putative transmembrane segments (IVS5 and IVS6) of the fourth homology domain are indicated by lines above the sequence. A peptide corresponding to the underlined residues in the SCLC-P amino acid sequence $(B)$ was used for the production of polyclonal antibodies. $C$, A comparison of the deduced amino acid sequences of six classes of $\mathrm{Ca}^{2+}$ channels with that of the SCLC-P clone in the vicinity of a unique acidic region. The sequences shown are the SCLC-P clone described in this manuscript (HumSCLC-P), the rabbit brain P-type Ca ${ }^{2+}$ channel (RabBrain-P) (Mori et al., 1991), the human brain $\mathrm{N}$-type $\mathrm{Ca}^{2+}$ channel (HumBrain-N) (Williams et al., 1992), the rat brain T-type Ca ${ }^{2+}$ channel (RatBrain-T) (Soong et al., 1993), the rabbit skeletal muscle L-type $\mathrm{Ca}^{2+}$ channel (RabSkeletal) (Tanabe et al., 1987), the rabbit cardiac muscle L-type Ca ${ }^{2+}$ channel (RabCardiac) (Mikami et al., 1989), and the rat brain L-type $\mathrm{Ca}^{2+}$ channel (RatBrain-L) (Hui et al., 1991).

as follows: (1) $1 \mathrm{hr}$ without antibody to block nonspecific binding sites, (2) $8 \mathrm{hr}$ with $5 \mathrm{nM}$ affinity-purified anti-peptide antibody, and (3) $1 \mathrm{hr}$ with alkaline phosphatase-conjugated goat anti-rabbit secondary antibody $(1: 10,000)$ (Jackson Immunoresearch). The strips were developed using 5-bromo-4-chloro-3-indolyl phosphate and nitro blue tetrazolium (Sigma). In some cases the anti-peptide antibody used in step 2 was preincubated for $1 \mathrm{hr}$ with $26 \mu \mathrm{M}$ peptide to determine nonspecific binding.

Immunofluorescence. Immunofluorescence was performed on cells in suspension at room temperature. The cells were pelleted at $6000 \mathrm{rpm}$ for $1 \mathrm{~min}$ and the supernatant was aspirated for solution changes. Cells were washed three times in PBS and fixed in 1\% paraformaldehyde containing $150 \mathrm{~mm}$ lysine for $30 \mathrm{~min}$. All subsequent incubations and washes werc in PBS, $0.1 \%$ cold watcr fish gclatin, $0.08 \%$ BSA, and $6 \%$ normal goat serum. Cells were incubation for $30 \mathrm{~min}$ in the absence of antibody and then for $70 \mathrm{~min}$ with $100 \mathrm{nM}$ affinity-purified anti-peptide antibody. In some cases the anti-peptide antibody was preincubated for $1 \mathrm{hr}$ with $26 \mu \mathrm{M}$ peptide to determine nonspecific binding. The cells were washed three times and incubated with fluorescein-conjugated goat anti-rabbit secondary antibody (1:200) (Jackson Immunoresearch) for $50 \mathrm{~min}$. After three additional washes, the cells were pelleted, resuspended in $30 \%$ glycerol, $12 \%$ Mowiol (Calbiochem), $120 \mathrm{~mm}$ Tris, pH 8.5 , and mounted on glass slides. Photographs were taken on a Zeiss microscope using a $63 \times$ oil-immersion objective.

\section{Incubation of $H 146$ cells with antibodies}

Prior to applying the antibodies to the H146 cells, both control (rabbit IgG, Sigma) and anti-peptide antibodies were dialyzed against RPMI for $48 \mathrm{hr}$ with one dialysate change at $24 \mathrm{hr}$. Antibodies were then diluted into the cancer cell suspension to the desired concentration $(0.02$ or $0.04 \mathrm{mg} / \mathrm{ml} \mathrm{IgG)} \mathrm{and} \mathrm{allowed} \mathrm{to} \mathrm{react} \mathrm{with} \mathrm{the} \mathrm{cells} \mathrm{for} 1 \mathrm{hr}$ at $37^{\circ} \mathrm{C}$. To affix the cells for patch-clamp recordings, the cell suspension was plated onto poly-L-lysine-coated (Sigma) coverslips and returned to $37^{\circ} \mathrm{C}$ for $1 \mathrm{hr}$. Thus, the cells were exposed to the antibodies for a total of $2 \mathrm{hr}$ prior to patch-clamp analysis. Experiments were carried out using cells that had been subcultured the previous day. For a given experiment, control and treatment cells were always taken from the same culture flask.

\section{Patch-clamp recordings}

Standard patch-clamp protocols were used to obtain whole-cell recordings of $I_{\mathrm{Na}}$ and $I_{\mathrm{C}_{\mathrm{a}}}$ (Hamill et al., 1981). Patch-clamp pipettes were fashioned from borosilicate glass (Kimax-51, Kimble Products, Vineland, NJ) and the tips coated with Sylgard (Dow Corning, Midland, MI) to reduce pipette capacitance. Pipettes typically had resistances of $\sim 2$ MS. Prior to eliciting voltage protocols, cells were maintained at the holding potential for $1 \mathrm{~min}$. Voltage clamping was performed with an L/M-EPC-7 patch-clamp amplifier (List Medical, Darmstadt, Germany). Signals were filtered through an 8-pole low-pass Bessel filter (Frequency Devices, Haverhill, MA) with a cutoff frequency of $3 \mathrm{kHz}$. Data acquisition and analysis were accomplished with pCLAMP software (Axon Instruments, Foster City, CA) using a PC-compatible 486 computer and Lab Master DMA TL- 1 interface (Axon Instruments). From the holding potential, $7-16$ consecutive depolarizations ranging from $-60 \mathrm{mV}$ to $+90 \mathrm{mV}$ in $10 \mathrm{mV}$ increments were applied to each cell. Pulses were of $350 \mathrm{msec}$ duration at a frequency of $0.2 \mathrm{~Hz}$ and sampled at $2.5 \mathrm{kHz}$. A $P / 4$ procedure (Armstrong and Bezanilla, 1977) was used to eliminate capacitative and leak currents. 


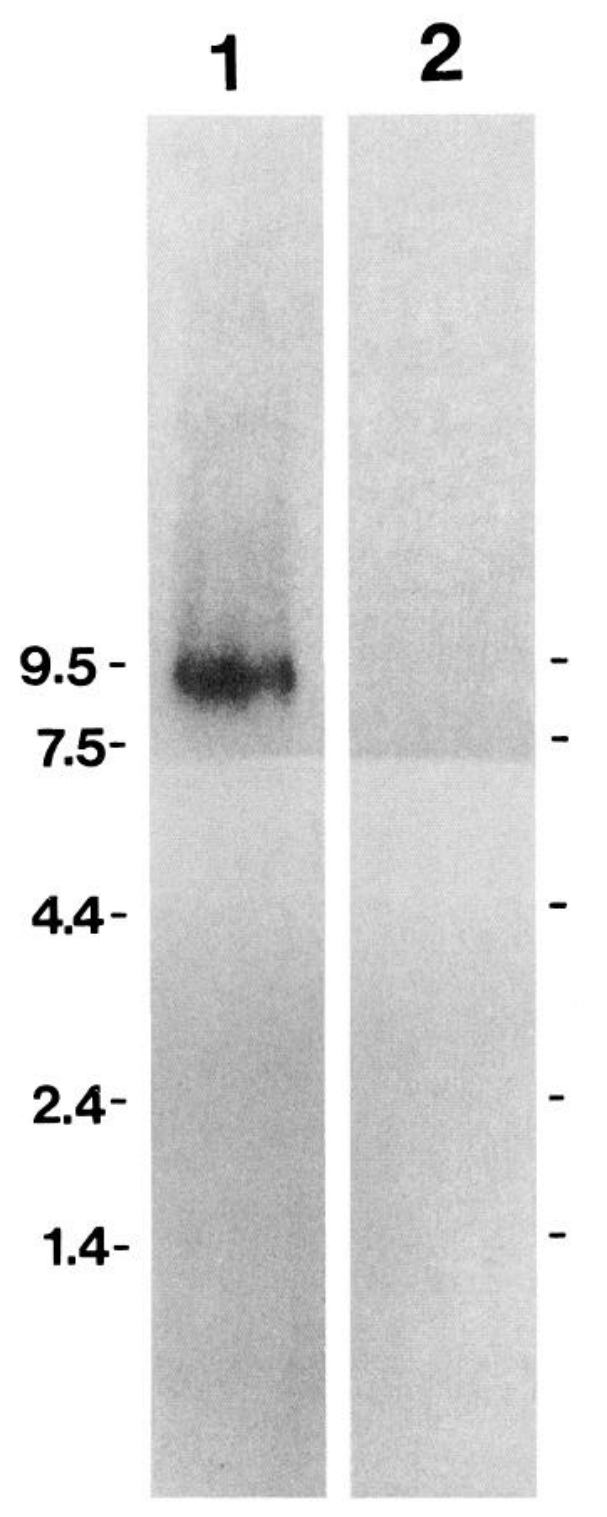

Figure 2. Autoradiogram of a Northern blot of RNA hybridized to an SCLC Ca ${ }^{2+}$ channel $\alpha$ subunit riboprobe. An SCLC-P riboprobe was hybridized with total RNA ( $50 \mu \mathrm{g} /$ lane) isolated from SCLC (lane 1) or muscle (lane 2) cell lines. Autoradiography was for $3 \mathrm{~d}$ at $-70^{\circ} \mathrm{C}$. An RNA ladder (GIBCO/Bethesda Research Labs) was used for size markers (in kilobases).

For all recordings, the patch-clamp pipettes were filled with $120 \mathrm{mM}$ $\mathrm{CsCl}, 20$ mм TEA-Cl, 11 mм EGTA-NaOH, 1 mм CaCl, 2 mм MgCl , and $10 \mathrm{~mm}$ HEPES-NaOH, $\mathrm{pH}$ 7.2. The external recording solution consisted of $130 \mathrm{~mm} \mathrm{NaCl}, 5 \mathrm{~mm} \mathrm{KCl}, 10 \mathrm{~mm} \mathrm{CaCl}_{2}$, and $10 \mathrm{~mm}$ HEPES-NaOH, pH 7.2. For all experiments in which the cells were exposed to $\omega$-AGA-IVA, $10 \mathrm{~mm} \mathrm{BaCl}_{2}$ was substituted for the $\mathrm{CaCl}_{2}$ in the bath solution. $\omega$-CgTx-GVIA (Sigma) and $\omega$-Aga-IVA were stored frozen at $-20^{\circ} \mathrm{C}$ as stocks after reconstitution. Stock solutions were diluted into the recording chamber to achieve the desired final concentration of drug (bath volumes were 1 or $2 \mathrm{ml}$ ). Nifedipine (Sigma) was dissolved in DMSO and stored at $4^{\circ} \mathrm{C}$. Before each experiment, the nifedipine stock was diluted to working stocks with distilled $\mathrm{H}_{2} \mathrm{O}$. All nifedipine experiments were performed in a darkened environment. To avoid time-dependent effects, cells were pretreated for $10 \mathrm{~min}$ with vehicle or drug and recordings were made $1 \mathrm{~min}$ after establishment of a whole-cell patch.

$I_{\mathrm{Na}}$ was taken as the peak transient component occurring within the first $5 \mathrm{msec}$. Peak $I_{\mathrm{C}}$ was measured as the maximum current between 18 and $60 \mathrm{msec}$ from the start of the depolarization. Plateau $I_{\mathrm{Ca}}$ was

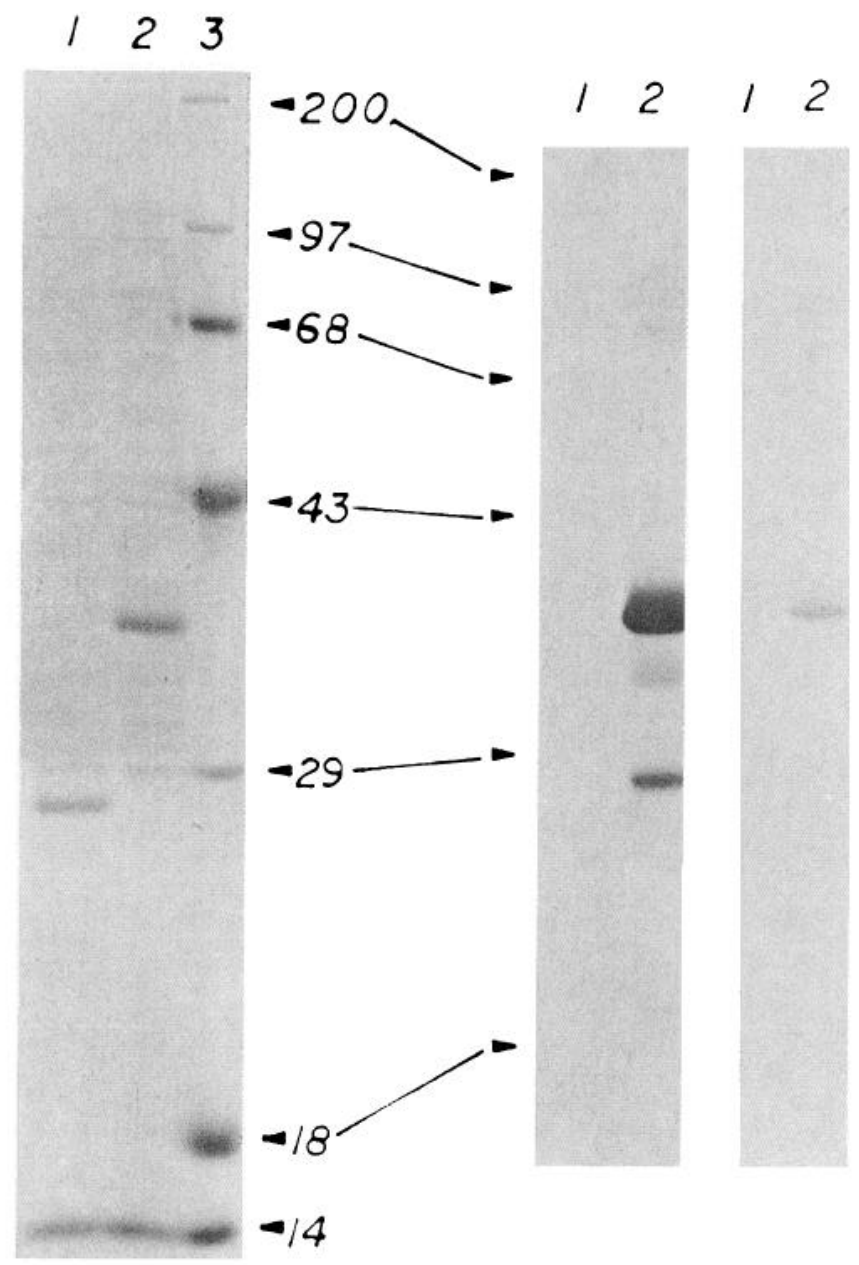

Figure 3. SDS-PAGE gel and Western blots of fusion-protein bacterial lysates using anti-peptide antibody. Total cell lysates from bacteria transformed with control fusion protein vector (lane I) or the SCLC-P recombinant fusion protein vector (lane 2) were electrophoresed on an SDS-PAGE gel and the gel was stained for protein (left). The sizes of the molecular weight markers (lane 3) (GIBCO/Bethesda Research Labs) are indicated (in kilodaltons). Duplicate lanes were transferred to nitrocellulose strips for blotting with an anti-peptide antibody in the absence (middle) or presence (right) of competing peptide.

measured as the current at the end of the $350 \mathrm{msec}$ pulse. To avoid discrepancies due to cell size, current values for each cell were divided by the capacitance of that cell and currents were reported as current density $(\mathrm{pA} / \mathrm{pF})$. Experiments were done in pairs; each data set was normalized against its own control and results were pooled across experiments to obtain mean \pm SEM. Student's $t$ test was used for statistical analyses; $p<0.05$ was considered significant.

\section{Results}

Isolation and characterization of SCLC calcium channel cDNA clones

Partial cDNA clones corresponding to putative $\mathrm{Ca}^{2+}$ channel $\alpha_{1}$ subunits were isolated from human H146 SCLC cells using the polymerase chain reaction (PCR). The sequences of the SCLC clones obtained were compared to the published sequences of $\mathrm{Ca}^{2+}$ channels. One of these clones, SCLC-P (345 bp), is most highly homologous to the presumptive $\mathrm{P}$-type $\mathrm{Ca}^{2+}$ channels isolated from rabbit (called B1; Mori et al., 1991) and rat brain (called rbA; Starr et al., 1991). The degree of homology to the B1 transcript is $89.7 \%$ at the nucleotide level (Fig. $1 \mathrm{~A}$ ) and $98.2 \%$ 
a

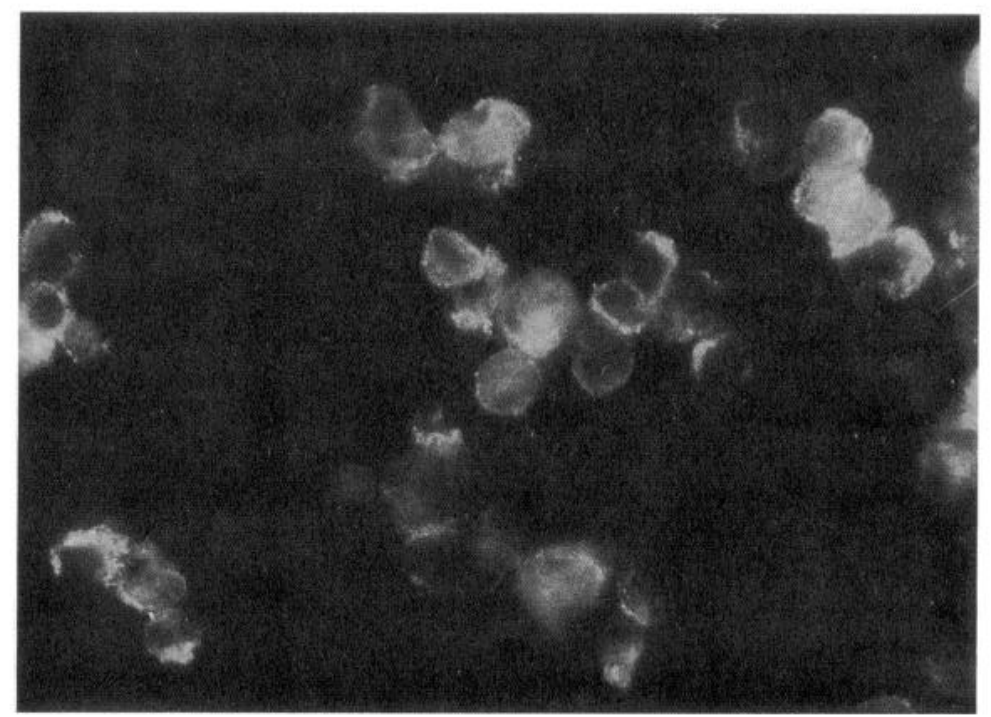

b

Figure 4. Immunofluorescence staining of SCLC cells with anti-peptide antibody. H146 SCLC cells were stained with anti-peptide antibody in the absence $(a)$ or presence $(b)$ of competing peptide.

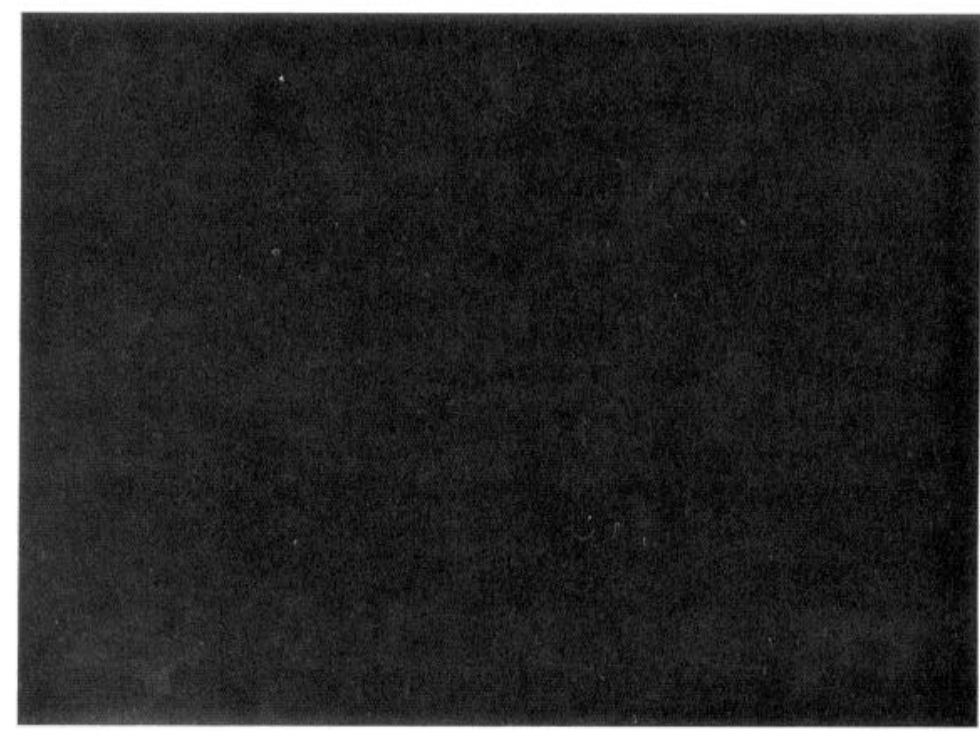

at the amino acid level (Fig. 1B), whereas homology to the skeletal muscle L-type channel (Tanabe et al., 1987) is $63.1 \%$ and $54.7 \%$, respectively (not shown). The high degree of homology suggests that this clone represents the human homolog of the rabbit brain channel described by Mori et al., and not a novel form of calcium channel. This clone contains a small region of particular interest: a short stretch ( 24 nucleotides) coding for very acidic amino acids that appears to be unique to this type of calcium channel (Fig. $1 C$ ). This acidic region is not found in any of the three classes of L-type channels (Tanabe et al., 1987; Mikami et al., 1989; Hui et al., 1991; Snutch et al., 1991) or in the presumptive N-type channels that have been described to date (Dubel et al., 1992; Williams et al., 1992), nor is this sequence found in a member of the low-voltage-activated (T-type) calcium channel family recently cloned from rat brain (Soong et al., 1993). It is also not present in a novel channel from rabbit brain (Niidome et al., 1992) (not shown).

Northern analysis was used to detect expression of mRNA transcripts corresponding to the SCLC-P clone (Fig. 2). The SCLC-P clone hybridized to a single mRNA of approximately $9.0 \mathrm{~kb}$ from the H146 SCLC cell line (lane 1) but not to any mRNA isolated from a muscle cell line (lane 2) that was used as a negative control. An L-type calcium channel probe detected a $6.5 \mathrm{~kb}$ band in muscle RNA, thereby demonstrating the integrity of the RNA (not shown). The $9.0 \mathrm{~kb}$ message in SCLC is approximately the same size as that reported for the B1 calcium channel transcript in rabbit brain (Mori et al., 1991). To determine if expression of this $\mathrm{Ca}^{2+}$ channel mRNA is common to other SCLC cell lines, total RNA was prepared from H345 and $\mathrm{H} 209$ cells. Clone SCLC-P hybridized to a single $9.0 \mathrm{~kb}$ mRNA from these cells as well (not shown).

\section{Production and characterization of polyclonal anti-peptide antibodies}

As described above, we have found evidence for the presence of the transcript for a presumptive P-type calcium channel in 
human SCLC cells. To study the expression of the calcium channel protein, antibodies were raised to a unique acidic peptide, IDVEDEDSDEDEF, corresponding to a cDNA sequence in the IV S5-S6 linker region of SCLC-P (Fig. $1 B$ ). This peptide has not been found in any of the other classes of calcium channels cloned to date (Fig. 1C) and is predicted to be located on the extracellular side of the membrane.

To detcrminc the specificity of the antibodies, they were used for western blotting of the SCLC-P clone expressed as a fusion protein with GST (glutathione-S-transferase). Total cell lysates from bacterial cell cultures were analyzed by sodium dodecyl sulfate-polyacrylamide gel electrophoresis (SDS-PAGE) (Fig. 3). The 27,500 Da GST protein was the major band seen in lysates from cells transformed with control vector (no SCLC-P insert) and induced with IPTG (Fig. 3, left, lane 1). When cells were transformed with recombinant vector containing the SCLC-P clone insert, a major inducible protein band of approximately 40,000 Da was seen, which corresponds to the predicted size of the fusion protein (Fig. 3, left, lane 2). Western blot analysis revealed that the antibody bound to the 40,000 Da SCLC-PGST fusion protein band from recombinant cell lysates (Fig. 3, middle, lane 2). Some smaller bands were also seen that are believed to be degradation products of the fusion protein. However, the antibody did not bind to any of the proteins in the control cellular lysate (Fig. 3, middle, lane 1). In addition, binding to the fusion protein was inhibited by preincubation of antibody with peptide (Fig. 3, right, lane 2). Thus, the anti-peptide antibody bound specifically to the SCLC-P portion of the fusion protein.

We were unable to detect the SCLC calcium channel protein, or any other protein, by immunoblotting total cell lysates from $\mathrm{H} 146$ cells. This result is not surprising because the channel is likely to make up too small a portion of the total cellular protein to be detected by this method. Therefore, at least partial purification of the protein may be necessary before it can be detected.

Immunofluorescence was performed on nonpermeabilized SCLC cells to determine if the anti-peptide antibody recognized a native molecule on the cell surface. Antibody bound to the surface of $\mathrm{H} 146$ cells (Fig. $4 a$ ). Binding was inhibited by preincubation of antibody with peptide (Fig. $4 b$ ). Similar results were obtained with the H345 and H209 SCLC cell lines (not shown). Very low background levels of binding of control rabbit IgG were detected, but binding was not blocked by preincubation with peptide (not shown). These results indicate that the antipeptide antibody recognizes a protein that is expressed on the surface of SCLC cells and are consistent with the proposed localization of the antigen (VGCC) to the cell membrane.

\section{Inhibition of calcium currents by anti-peptide antibodies}

The anti-peptide antibodies are predicted to bind near the extracellular entrance to the pore of the calcium channel; thus, it is possible that binding may inhibit channel activity. Inhibition of calcium currents in H146 cells was examined using the wholecell patch-clamp technique. Inward currents from H146 cells were elicited at a range of potentials from a holding potential of $-80 \mathrm{mV}$. In cells exposed to $10 \mathrm{mM}\left[\mathrm{Ca}^{2+}\right]_{o}$, the whole-cell currents were characterized by an initial transient component consisting of current carried by sodium $\left(I_{\mathrm{Na}}\right)$ and a second longlasting component, the calcium current $\left(I_{\mathrm{Ca}}\right)$ (see Figs. $5 A, 6 A$ ). $\mathrm{H} 146$ cells were treated with control or anti-peptide antibodies $(0.02 \mathrm{mg} / \mathrm{ml} \mathrm{IgG)}$ for $2 \mathrm{hr}$ prior to patch-clamp analysis. Both peak $I_{\mathrm{Ca}}$ (measured at the beginning of the depolarization) and
A
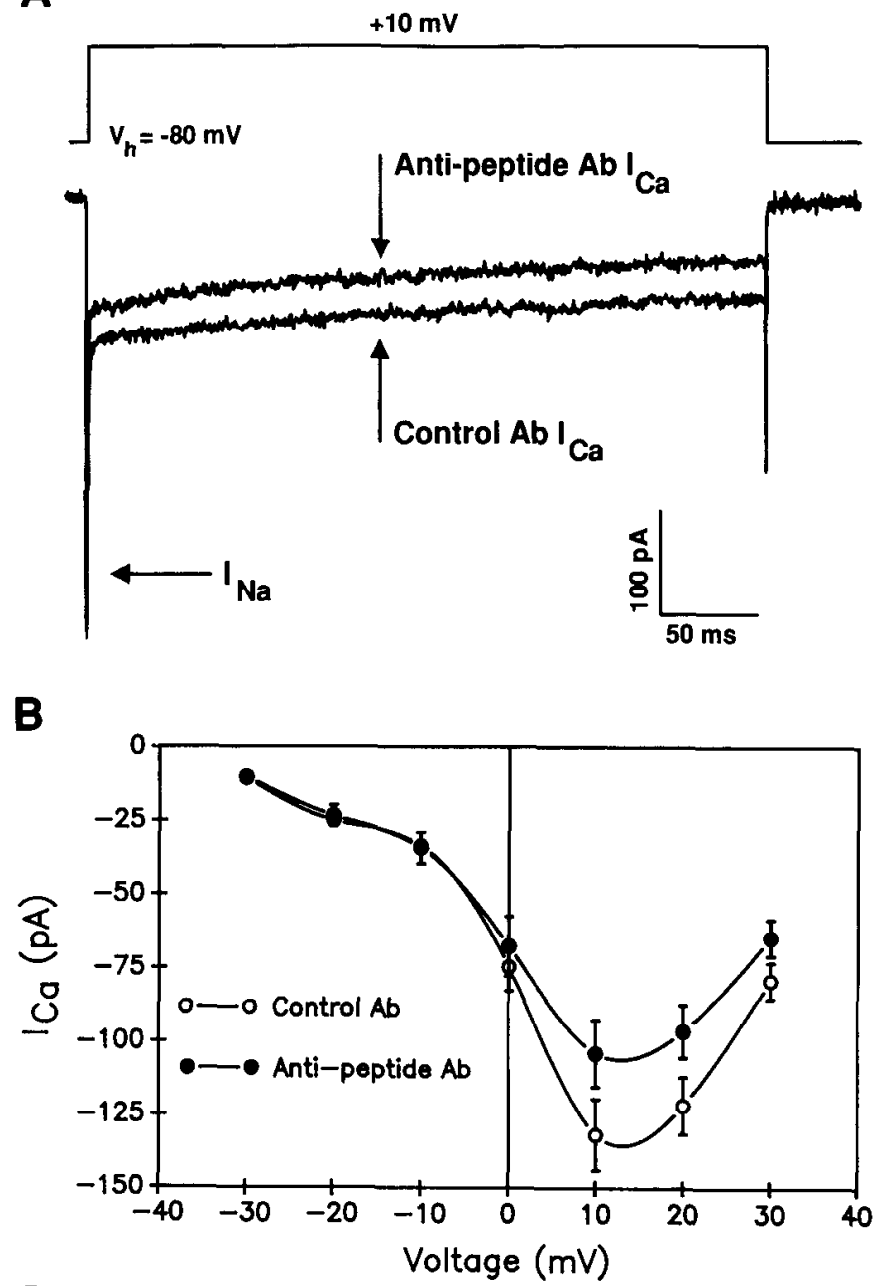

C

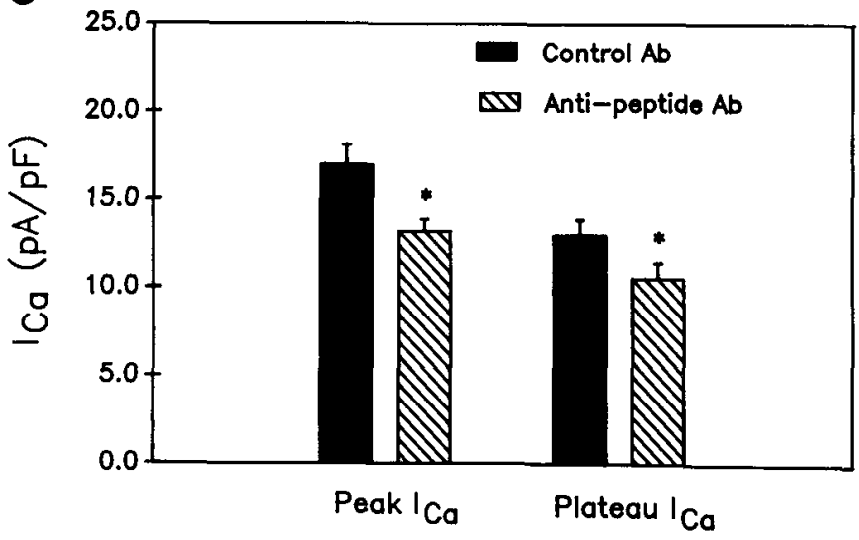

Figure 5. Inhibition of calcium currents in H146 SCLC cells by antipeptide antibodies. $A$, Representative current recordings from a cell treated with control antibodies and a cell treated with anti-peptide antibudies $\left(0.02 \mathrm{mg} / \mathrm{ml}\right.$ IgG) for $2 \mathrm{hr}$. $I_{\mathrm{Ca}}$ was elicited with a depolarization to $+10 \mathrm{mV}$ from a holding potential of $-80 \mathrm{mV}$ in $10 \mathrm{mM}\left[\mathrm{Ca}^{2+}\right]_{o} . B$, Current-voltage relationships for cells treated with control antibodies and cells treated with anti-peptide antibodies $(0.02 \mathrm{mg} / \mathrm{ml} \mathrm{lgG})$. Curves are the average of 33 control cells and 25 treatment cells. Error bars are SEM. Peak $I_{\mathrm{Ca}}$ is plotted. $C$, Summary of data obtained from the cells described in $B$. Bar graphs show the effect of the anti-peptide antibodies on peak (maximal $I_{\mathrm{Ca}}$ at the beginning of the depolarization) and plateau $I_{\mathrm{Ca}}$ (measured as the maximal $I_{\mathrm{Ca}}$ at the end of the stimulus). ${ }^{*}, p<$ 0.05 . 
A

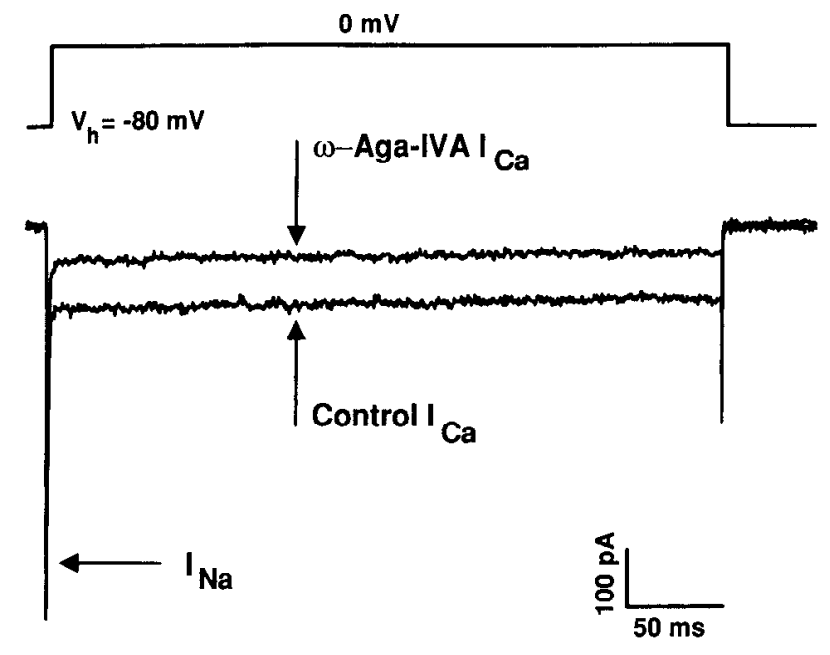

B

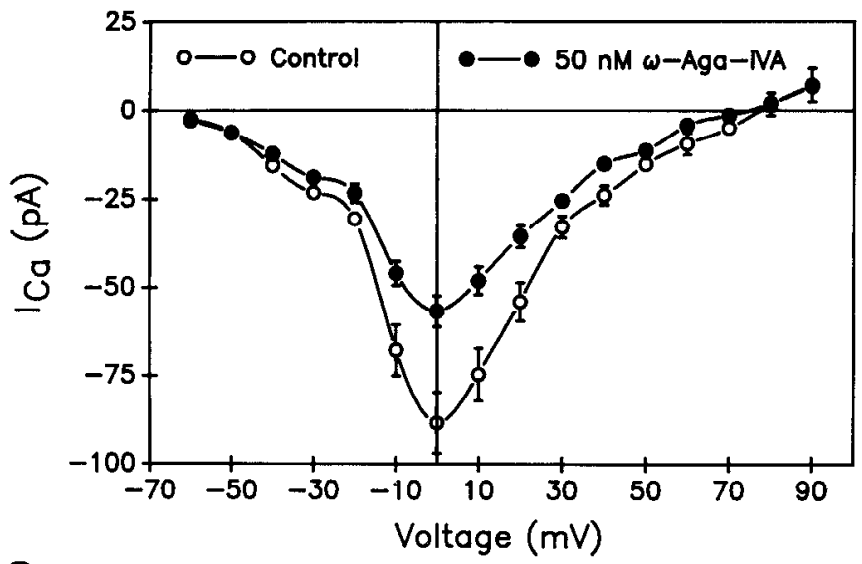

C

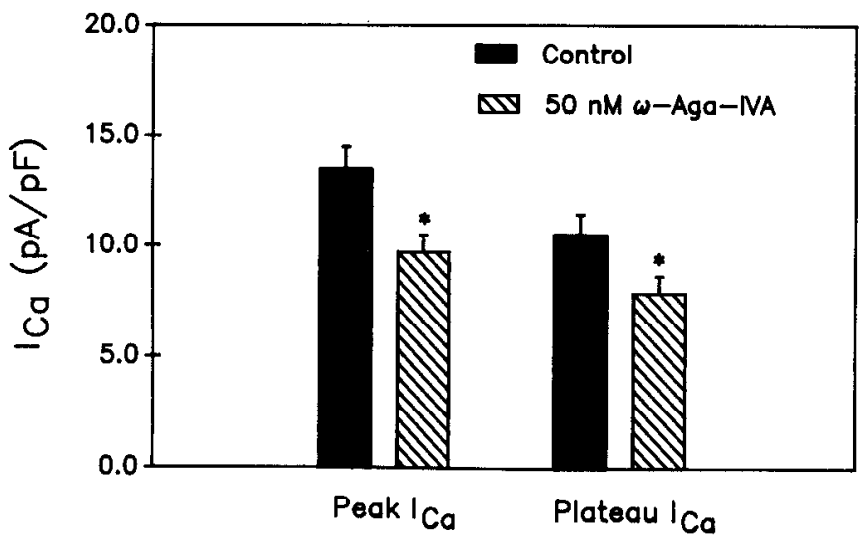

Figure 6. Inhibition of calcium currents in H146 SCLC cells by $\omega$-agatoxin IVA. $A$, Representative current recordings from a control cell (untreated) and a cell pretreated for $10 \mathrm{~min}$ with $50 \mathrm{~nm} \omega$-Aga-IVA. $I_{\mathrm{Ca}}$ was elicited with a depolarization to $+10 \mathrm{mV}$ from a holding potential of $-80 \mathrm{mV} . B$, Current-voltage relationships for control cells (untreated) and for cells treated with $50 \mathrm{nM} \omega$-Aga-IVA. Curves are the average of 35 control cells and 32 treatment cells. Error bars are SEM. Peak $I_{\mathrm{Ca}}$ is plotted. Note that peak $I_{\mathrm{C}}$ is shifted $10 \mathrm{mV}$ compared to Figure 5 due to the change in the charge carrier from calcium to barium. $C$. Summary of the data obtained from the cells described in $B$. Bar graphs show the effect of the toxin on peak and plateau $I_{\mathrm{C} \cdot}{ }^{*}, p<0.025$. plateau $I_{\mathrm{CA}}$ (measured at the end of the $350 \mathrm{msec}$ depolarization) were studied because other reports suggest that P-type channels do not inactivate with long depolarization (Llinás et al., 1989; Regan et al., 1991; Usowicz et al., 1992). Peak $I_{\text {Ca }}$, which was maximal at $+10 \mathrm{mV}$, was reduced by $20 \pm 6 \%$ (mean \pm SEM, $n=25$ cells, $p<0.05$ ) in cells treated with anti-peptide antibodies relative to cells treated with control antibodies (Fig. 5). The anti-peptide antibodies did not inhibit peak $I_{\mathrm{Ca}}$ evoked at potentials below $+10 \mathrm{mV}$, although peak $I_{\mathrm{Ca}}$ measured from $+10 \mathrm{mV}$ to $+30 \mathrm{mV}$ was similarly reduced by approximately $20 \%$. The plateau $I_{\mathrm{Ca}}$ measured during depolarization to +10 $\mathrm{mV}$ was likewise diminished by $19 \pm 7 \%(n=25$ cells, $p<$ 0.05 ) after exposure to the anti-peptide antibodies (Fig. $5 C$ ). Increasing the concentration of antibody to $0.04 \mathrm{mg} / \mathrm{ml}$ did not increase the amount of reduction observed; therefore, a concentration of $0.02 \mathrm{mg} / \mathrm{ml} \mathrm{IgG}$ was used for all subsequent experiments.

To confirm that the antibodies reduce $I_{\mathrm{Ca}}$ by specifically inhibiting the action of calcium channels, we assessed antibody effects on $I_{\mathrm{Na}}$ in the same cells used for $I_{\mathrm{Ca}}$ analyses. Accordingly, cells that had been incubated in the anti-peptide antibodies exhibited a maximal $I_{\mathrm{Na}}$ of $54.3 \pm 5.5 \mathrm{pA} / \mathrm{pF}(n=25)$, which was not significantly different from the control $I_{\mathrm{Na}}$ of $61.4 \pm 5.1$ $\mathrm{pA} / \mathrm{pF}(n=33, p>0.1)$ (not shown).

If the antibodies inhibit a P-type calcium channel in HI46 cells, then it would be expected that (1) $I_{C_{a}}$ should be sensitive to $\omega$-Aga-IVA, (2) the inhibitory effect of the antibodies and the $\omega$-Aga-IVA on the $I_{\mathrm{Ca}}$ should not be additive, and (3) the antibodies should reduce the $I_{\mathrm{Ca}}$ in the presence of a DHP antagonist and $\omega$-CgTx-GVIA. To test these hypotheses, we performed the following cxperiments.

To assess the effect of $\omega$-Aga-IVA on calcium channel activity, $10 \mathrm{mM} \mathrm{BaCl}_{2}$ was substituted for the $\mathrm{CaCl}_{2}$ in the bath solution. This permitted comparison with previous reports on the effects of $\omega$-Aga-IVA (Regan et al., 1991; Mintz et al., 1992b). Treatment of $\mathrm{H} 146$ cells with $50 \mathrm{~nm} \omega$-Aga-IVA for $10 \mathrm{~min}$ reduced the magnitude of the peak $I_{\mathrm{Ca}}$ by $28 \pm 6 \%(n=29$ cells, $p<$ 0.005 ) (Fig. 6). Similarly, the plateau phase of the $I_{\mathrm{Ca}}$ was reduced by $26 \pm 7 \%(n=29, p<0.025)$ (Fig. $6 C)$. The shape of the current-voltage curves and the reversal potential were unchanged after incubation with toxin; only the magnitudes of the currents were reduced. In addition, $I_{\mathrm{Na}}$ was not significantly affected by the $\omega$-Aga-IVA (not shown).

The effect of $\omega$-Aga-IVA was also assessed on $\mathrm{H} 146$ cells that were pretreated for $2 \mathrm{hr}$ with anti-peptide antibodies and subsequently exposed to $50 \mathrm{nM} \omega$-Aga-IVA (Fig. 7). Peak $I_{\mathrm{Ca}}$ was reduced by $32 \pm 8 \%(n=18$ cells, $p<0.05)$; a rcduction similar to that observed when the toxin was applied alone. Although it appears that the toxin and antibody combination may inhibit $I_{\mathrm{Ca}}$ slightly more than either agent alone, the difference is not statistically significant. These results support the hypothesis that the antibody and the toxin act on the same type of calcium channel in $\mathrm{H} 146$ cells.

H146 cells are known to express $I_{\mathrm{Ca}}$ that is sensitive to both DHP antagonists and $\omega$-CgTx-GVIA (Viglione et al., 1993). P-type calcium channels, however, are insensitive to these agents (Mintz et al., 1992b). Therefore, we examined whether the antibodies were effective at reducing the $I_{\mathrm{Ca}}$ that remained after their application. In the absence of antibody, $10 \mu \mathrm{M}$ nifedipine and $1 \mu \mathrm{M} \omega$-CgTx-GVIA inhibit $40 \pm 6 \%$ of peak $I_{\mathrm{Ca}}$ and $47 \pm$ $6 \%$ of plateau $I_{\mathrm{Ca}}$ (Fig. 7). With these additional agents in the recording solution, the anti-peptide antibodies reduced the peak 


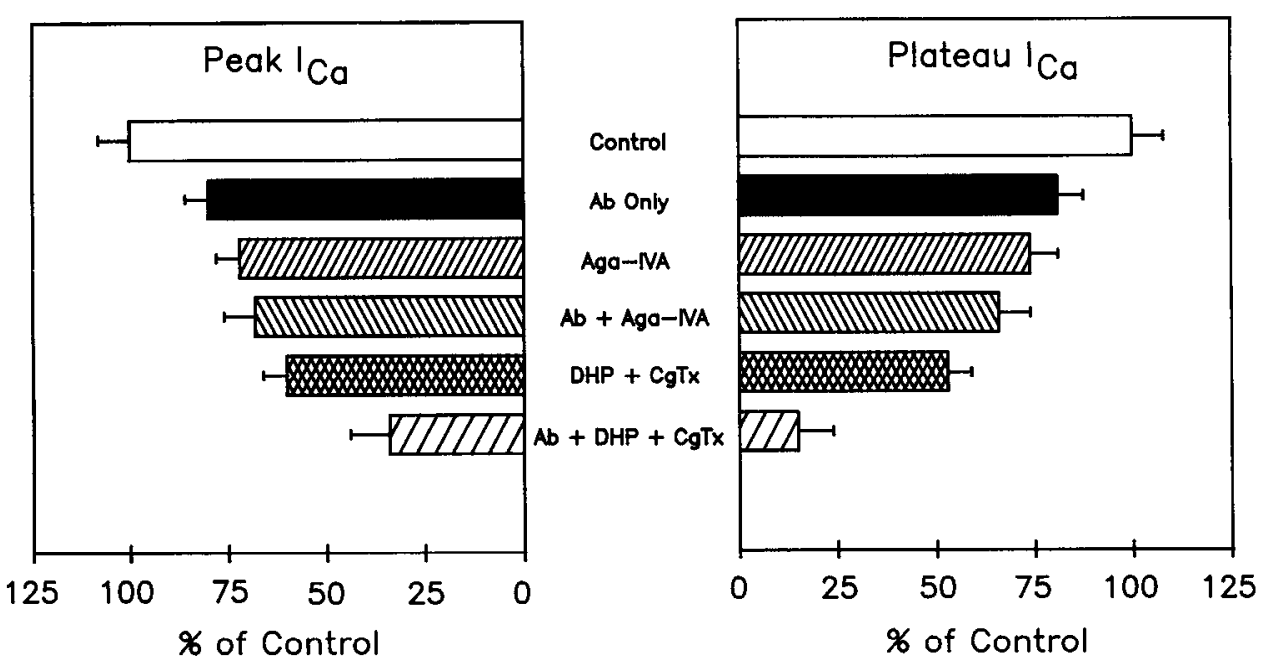

Figure 7. Inhibition of calcium currents in H146 SCLC cells by combinations of anti-peptide antibodies and toxins or DHP. Prior to recording $I_{\mathrm{Ca}}$, $\mathrm{H} 146$ cells were treated as follows: $\mathrm{Con}$ trol, $0.02 \mathrm{mg} / \mathrm{ml}$ control IgG for $2 \mathrm{hr}$; $A b$ Only, $0.02 \mathrm{mg} / \mathrm{ml}$ anti-peptide antibody for $2 \mathrm{hr} ; A g a-I V A, 50 \mathrm{~nm} \omega$-AgaIVA for $10 \mathrm{~min} ; A b+A g a-I V A, 0.02$ $\mathrm{mg} / \mathrm{ml}$ anti-peptide antibodies for $2 \mathrm{hr}$ and then $50 \mathrm{~nm} \omega$-Aga-IVA for $10 \mathrm{~min}$; $D H P+C g T x, 10 \mu \mathrm{M}$ nifedipine plus 1 $\mu \mathrm{M} \omega$-CgTx-GVIA for $15 \mathrm{~min} ; A b+$ $D H P+C g T x, 0.02 \mathrm{mg} / \mathrm{ml}$ anti-peptide antibodies for $2 \mathrm{hr}$ and then $10 \mu \mathrm{M}$ nifedipine and $1 \mu \mathrm{M} \omega$-CgTx-GVIA for $15 \mathrm{~min}$. All reductions are significant $(p<0.05)$. The data for effect of the antibodies or $\omega$-Aga-IVA alone are duplicated from Figures 5 and 6 for comparison purposes. and plateau $I_{\text {Ca }}$ by $66 \pm 10 \%(n=16$ cells $)$ and $85 \pm 9 \%(n=$ 16 cells), respectively (Fig. 7). Notably, in the presence of nifedipine and $\omega$-CgTx-GVIA, the plateau $I_{C a}$ (where the nifedipinc is most effective) was reduced to a greater extent than the peak $I_{\text {Ca }}$. The anti-peptide antibodies and the $\omega$-Aga-IVA, on the other hand, were equally effective as inhibitors of peak and plateau $I_{\text {Ca }}$ (see Figs. 5, 6). When these experiments were carried out from a holding potential of $-40 \mathrm{mV}$ instead of $-80 \mathrm{mV}$, the antibodies were similarly effective, inhibiting the peak $I_{\mathrm{Ca}}$ by $70 \pm 9 \%(n=16$ cells $)$ and the plateau $I_{\mathrm{Ca}}$ by $78 \pm 8 \%(n$ $=16$ cells) (not shown). This observation agrees with published reports that $\mathrm{P}$-type channels are functional with a more depolarized holding potential (Regan et al., 1991). In conclusion, these results demonstrate that the anti-peptide antibodies act on a component of the current that remains after application of nifedipine and $\omega$-CgTx-GVIA.

\section{Discussion}

In the present study we describe the presence of a P-type VGCC $\alpha_{1}$ subunit in SCLC cells. We have isolated from human $\mathrm{H} 146$ SCLC cells a partial cDNA clone (SCLC-P) that is highly homologous to putative P-type VGCC $\alpha$, subunits cloned from rabbit (Mori et al., 1991) and rat (Starr et al., 1991) brain. Antibodies raised to a unique acidic peptide encoded by this cDNA clone inhibited calcium current induced by depolarizing potentials in SCLC cells. Current models of VGCC membrane topology suggest that relativcly little of the $\alpha_{1}$ subunit is exposed on the extracellular surface of the membrane. The acidic peptide against which our antibodies were generated is predicted to be located near the extracellular entrance to the channel pore just upstream of the SS1 and SS2 membrane-spanning domains (H5 segment) that are thought to line the pore of the channel, as evidenced by mutational analysis of the corresponding regions in sodium and potassium channels (Yellen et al., 1991; Heinemann et al., 1992) and, more recently, in a calcium channel (Tang et al., 1993). Our data support a model in which this region is exposed at the extracellular surface because the antipeptide antibodies bind extracellularly and interfere with calcium currents.

We have also shown that the P-type-specific toxin $\omega$-AgaIVA inhibits calcium currents in SCLC cells. It is worth noting that while the antibodies block approximately $20 \%$ of the cal- cium current, $\omega$-Aga-IVA blocks a larger percentage, approximately $28 \%$. However, the mechanism of the inhibitory effect of the antibody is not known; it could result either from the obstruction of the open channel or by preventing the channel from achieving an open conformation. Thus, there is no reason to expect complete inhibition of channel activity by the antibody because, for example, it may only partially occlude the channel pore. It could be that the agatoxin provides a more complete block of channel function. Another possibility is that the antibody inhibits only a subclass of P-type channels while the toxin inhibits additional channcls. Notably, the nonadditivity of the inhibitory effects of toxin and anti-peptide antibodies is consistent with their action on the same type of channel. While apparent differences in the functional properties of a putative P-type transcript (BI) expressed in Xenopus oocytes and P-type calcium channels characterized in native tissues have been described (Sather et al., 1993), these differences may be attributable to the expression system. Our results characterizing native expression in SCLC cells support the hypothesis that the SCLC-P transcript encodes a P-type channel.

Neither the anti-peptide antibodies nor the $\omega$-Aga-IVA cause a complete block of calcium currents because SCLC cells have multiple types of VGCCs. In addition to the SCLC-P clone described here, we have isolated partial cDNAs corresponding to the $\alpha_{1}$ subunit of L-type VGCCs from H146 SCLC cells (Barry and Froehner, 1991). The presence of L-type VGCCs is consistent with the known inhibitory effects of DHP antagonists on calcium currents (Pancrazio et al., 1992). Our anti-peptide antibodies inhibit a component of the calcium current that is not blocked by application of inhibitors of L-type and N-type calcium channels (nifedipine and $\omega-\mathrm{CgTx}-\mathrm{GVIA}$, respectively). This data demonstrates the specificity of the antibodies for P-type calcium channels. It is interesting that even in the presence of anti-peptide antibodies, nifedipine, and $\omega$-CgTx-GVIA, some calcium current remains in these cells. Similar resistant currents have been reported in neuronal cells (Mintz. et al., 1992a).

A presynaptic calcium channel that regulates cholinergic transmitter release from the mammalian motor nerve terminal is thought to be the target of autoantibodies in the neuromuscular disease LES, which is commonly associated with SCLC (Vincent et al., 1989). Although it is not known which type of VGCC is the relevant target for LES autoantibodies, several 
studies have provided evidence for binding of LES antibodies to either N-type or L-type VGCCs. LES IgG immunoprecipitates $\omega$-CgTx-GVIA receptor complexes implicating $\mathrm{N}$-type channels (Sher et al., 1989, 1990; Leys et al., 1991). The results of patch-clamp experiments suggest inhibition of L-type VGCCs by LES antibodies (Peers et al., 1990). However, the release of acetylcholine at the mammalian neuromuscular junction is not inhibited by $\omega$-CgTx-GVIA (Olivera et al., 1985; Sano et al., 1987; Du Luca et al., 1991; Protti et al., 1991) or DHPs (Atchison, 1989; Burges and Wray, 1989). On the other hand, the rèlease of acetylcholine is inhibited by FTX (Uchitel et al., 1992) and $\omega$-Aga-IVA (Kim et al., 1993), implicating P-type channels in this process. Thus, the P-type calcium channel that we describe in SCLC cells may be a candidate for an SCLC antigen involved in the induction of LES. Evidence in our preliminary experiments (Viglione and Kim, 1993) demonstrating that LES IgG indeed downregulates the P-type calcium channel in SCLC cells is consistent with this proposal. It may now be possible to test the role of P-type channels in LES by injecting animals with either a fusion protein containing the SCLC-P clone or with the acidic peptide itself and examining the animals for the development of LES symptoms. Immunoreactivity of LES sera with two calcium channel-associated proteins, the $\beta$-subunit (Rosenfeld et al., 1993) and synaptotagmin (Leveque et al., 1992), has been reported. Therefore, it is worth considering that LES autoantibodies may cross-react with several different types of VGCCs due to the presence of homologous epitopes on their $\alpha_{1}$ subunits or to the sharing of accessory subunits or other associated proteins.

\section{References}

Armstrong CM, Bezanilla F (1977) Inactivation of the sodium channel. II. Gating current experiments. J Gen Physiol 70:567-590.

Atchison WD (1989) Dihydropyridine-sensitive and -insensitive components of acetylcholine release from rat motor nerve terminals. $J$ Pharmacol Exp Ther 251:672-678.

Barry ELR, Froehner SC (1991) Neuronal-like calcium channel sequences from a human small cell carcinoma of the lung cell line. J Cell Biol 115:466A.

Bradley JE, Bishop GA, St.John T, Frelinger JA (1988) A simple rapid method for the purification of poly $A^{+}$RNA. Biotechnology 6:114116.

Burges J, Wray DW (1989) Effect of the calcium-channel agonist CGP 28392 on transmitter release at mouse neuromuscular junctions. Ann NY Acad Sci 560:297-300.

Chomczynski P, Sacchi N (1987) Single-step method of RNA isolation by acid guanidinium thiocyanate-phenol-chloroform extraction. Anal Biochem 162:156-159.

De Aizpurua HJ, Lambert EH, Griesmann GE, Olivera BM, Lennon VA (1988) Antagonism of voltage-gated calcium channels in small cell carcinomas of patients with and without Lambert-Eaton myasthenic syndrome by autoantibodies, $\omega$-conotoxin and adenosine. Cancer Res 48:4719-4724.

Dubel SJ, Starr TVB, Hell J, Ahlijanian MK, Enyeart JJ, Catterall WA, Snutch TP (1992) Molecular cloning of the $\alpha-1$ subunit of an $\omega$-conotoxin-sensitive calcium channel. Proc Natl Acad Sci USA 89:50585962.

Du Luca A, Rand MJ, Reid JJ, Story DF (1991) Differential sensitivities of avian and mammalian neuromuscular junctions to inhibition of cholinergic transmission by omega-conotoxin GVIA. Toxicon 29:311-320.

Ellinor PT, Zhang J, Randall AD, Zhou M, Schwarz TL, Tsien RW, Horne WA (1993) Functional expression of a rapidly inactivating neuronal calcium channel. Nature 363:455-458.

Fukuoka T, Engel AG, Lang B, Newsome-Davis J, Prior C, Wray D (1987) Lambert-Eaton myasthenic syndrome: I. Early morphological effects of IgG on the presynaptic membrane active zones. Ann Neurol 22:193-199.
Gazdar AF, Carney DN, Russell EK, Sims HL, Baylin SB, Bunn PA, Guccion JG, Minna JD (1980) Establishment of continuous, clonable cultures of small-cell carcinoma of the lung which have amine precursor uptake and decarboxylation cell properties. Cancer Res 40: 3502-3507.

Hamill OP, Marty A, Neher E, Sakmann B, Sigworth FJ (1981) Improved patch-clamp techniques for high-resolution current recordings from cells and cell-free membrane patches. Pfluegers Arch 391:85100.

Heinemann SH, Terlau H, Stuhmer W, Imoto K, Numa S (1992) Calcium channel characteristics conferred on the sodium channel by single mutations. Nature 356:441-443.

Hillman D, Chen S, Aung TT, Cherskey B, Sugimori M, Llinás R (1991) Localization of P-type $\mathrm{Ca}^{2+}$ channels in the central nervous system. Proc Natl Acad Sci USA 88:7076-7080.

Hillyard DR, Monje VD, Mintz IM, Bean BP, Nadasdi L, Ramachandran J, Milijanich G, Azimi-Zoonooz A, McIntosh JM, Cruz LJ, Imperial JS, Olivera BM (1992) A new conus peptide ligand for mammalian presynaptic $\mathrm{Ca}^{2+}$ channels. Neuron 9:69-77.

Hui A, Ellinor PT, Krizanova O, Wang J-J, Diebold RJ, Schwartz A (1991) Molecular cloning of multiple subtypes of a novel rat brain isoform of the $\alpha 1$ subunit of the voltage-dependent calcium channel. Neuron 7:35-44.

Kim YI (1986) Passively transferred Lambert-Eaton syndrome in mice receiving purified IgG. Muscle Nerve 9:523-530.

Kim YI, Neher E (1988) IgG from patients with Lambert-Eaton Syndrome blocks voltage-dependent calcium channels. Science 239:405408.

Kim YI, Longacher JM, Viglione MP (1993) Omega-agatoxin IVA blocks evoked quantal transmitter release at the mammalian neuromuscular junction. Mol Biol Cell 4:428a.

Lang B, Newsome-Davis J, Prior C, Wray D (1983) Antibodies to motor nerve terminals: an electrophysiological study of human myasthenic syndrome transferred to mouse. J Physiol (Lond) 344:335345.

Leveque C, Hoshino T, David P, Shoji-Kasai Y, Leys K, Omori A, Lang B, El Far O, Sato K, Martin-Moutot N, Newsome-Davis J, Takahashi M, Seagar MJ (1992) The synaptic vesicle protein synaptotagmin associates with calcium channels and is a putative Lambert-Eaton myasthenic syndrome antigen. Proc Natl Acad Sci USA 89:3625-3629.

Leys K, Lang B, Johnston I, Newsome-Davis J (1991) Calcium channel autoantibodies in the Lambert-Eaton myasthenic syndrome. Ann Neurol 29:307-314.

Llinás R, Sugimori M, Lin JW, Cherksey B (1989) Blocking and isolation of a calcium channel from neurons in mammals and cephalopods utilizing a toxin fraction (FTX) from funnel-web spider poison. Proc Natl Acad Sci USA 86:1689-1693.

Llinás R, Sugimori M, Hillman DE, Cherksey B (1992) Distribution and functional significance of the P-type voltage-dependent calcium channels in the mammalian central nervous system. Trends Neurosci 15:351-355.

Mikami A, Imoto $\mathrm{K}$, Tanabe $\mathrm{T}$, Niidome $\mathrm{T}$, Mori $\mathrm{Y}$, Takeshima $\mathrm{H}$, Narumiya S, Numa $\mathbf{S}$ (1989) Primary structure and functional expression of the cardiac dihydropyridine-sensitive calcium channel. Nature 340:230-233.

Miller RJ (1987) Multiple calcium channels and neuronal function. Science 235:46-52.

Mintz IM, Adams ME, Bean BP (1992a) P-type calcium channels in rat central and peripheral neurons. Neuron 9:85-95.

Mintz IM, Venema VJ, Swiderek KM, Lee TD, Bean BP, Adams ME (1992b) P-type calcium channels blocked by the spider toxin $\omega$-AgaIVA. Nature 355:827-829.

Mori Y, Friedrich T, Kim M-S, Mikami A, Nakai J, Ruth P, Bosse E, Hofmann F, Flockerzi V, Furuichi T, Mikoshiba K, Imoto K, Tanabe $T$, Numa S (1991) Primary structure and functional expression from complementary DNA of a brain calcium channel. Nature 350:398402.

Niidome T, Kim M-S, Friedrich T, Mori Y (1992) Molecular cloning and characterization of a novel calcium channel from rabbit brain. FEBS Lett 308:7-13.

Olivera BM, Gray WR, Zeikus R, Michael McIntosh J, Vargas J, Victoria de Santos JR, Cruz LJ (1985) Peptide neurotoxins from fishhunting cone snails. Science 230:1338-1343.

Pancrazio JJ, Viglione MP, Tabbara IA, Kim YI (1989) Voltage- 
dependent ion channels in small-cell lung cancer cells. Cancer Res 49:5901-5906.

Pancrazio JJ, Oie HK, Kim YI (1992) Voltage-sensitive calcium channels in a human small-cell lung cancer cell line. Acta Physiol Scand 144:463-468.

Peers C, Lang R, Newsome-Davis J, Wray DW (1990) Selective action of myasthenic syndrome antibodies on calcium channels in a rodent neuroblastoma and glioma cell line. J Physiol (Lond) 421:293-308.

Protti DA, Szczpak L, Scornik FS, Uchitel OD (1991) Effect of $\omega$-conotoxin GVIA on neurotransmitter release at the mouse neuromuscular junction. Brain Res 557:336-339.

Regan LJ, Sah DWY, Bean BP (1991) Calcium channels in rat central and peripheral neurons: high-threshold current resistant to dihydropyridine blockers and $\omega$-conotoxin. Neuron 6:269-280.

Roberts A, Perera S, Lang B, Vincent A, Newsome-Davis J (1985) Paraneoplastic myasthenic syndrome IgG inhibits ${ }^{45} \mathrm{Ca}^{2+}$ flux in a human small cell carcinoma line. Nature 317:737-739.

Rosenfeld MR, Wong E, Dalmau J, Manley G, Posner JB, Sher E, Furneaux HM (1993) Cloning and characterization of a LambertEaton Myasthenic Syndrome antigen. Ann Neurol 33:113-120.

Russel PJ, O'Mara SM, Raghavan D (1990) Ectopic hormone production by small cell undifferentiated carcinomas. Mol Cell Endocrinol 71:1-12.

Sano K, Enomoto K, Maeno T (1987) Effects of synthetic $\omega$-conotoxin, a new type $\mathrm{Ca}^{2+}$ antagonist on frog and mouse neuromuscular junction. Eur J Pharmacol 141:235-241.

Sather WA, Tanabe T, Zhang J-F, Mori Y, Adams ME, Tsien RW (1993) Distinctive biophysical and pharmacological properties of class A (BI) calcium channel $\alpha_{1}$ subunits. Neuron 11:291-303.

Sher E, Canal N, Piccolo G, Gotti C, Scoppetta C, Evoli A, Clementi F (1989) Specificity of calcium channel autoantibodies in LambertEaton myasthenic syndrome. Lancet ii:640-643.

Sher E, Pandiella A, Clementi F (1990) Voltage-operated calcium channels in small cell lung carcinoma cell lines: pharmacological, functional, and immunological properties. Cancer Res 50:3892-3896.

Silberstein L, Inestrosa NC, Hall ZW (1982) Aneural muscle cell cultures make synaptic basal lamina components. Nature 295:143-145.

Snutch TP, Reiner PB (1992) $\mathrm{Ca}^{2+}$ channels: diversity of form and function. Curr Biol 2:247-253.

Snutch TP, Tomlinson WI, Leonard JP, Gilbert MM (1991) Distinct calcium channels are generated by alternative splicing and are differentially expressed in the mammalian CNS. Neuron 7:45-57.
Soong TW, Stea A, Hodson CD, Dubel SJ, Vincent SR, Snutch TP (1993) Structure and functional expression of a member of the low voltage-activated calcium channel family. Science 260:1133-1136.

Starr TVB, Prystay W, Snutch TP (1991) Primary structure of a calcium channel that is highly expressed in the rat cerebellum. Proc Natl Acad Sci USA 88:5621-5625.

Tanabe T, Takeshima H, Mikami A, Flockerzi V, Takahashi H, Kangawa K, Kojima M, Matsuo H, Hirose T, Numa S (1987) Primary structure of the receptor for calcium channel blockers from skeletal muscle. Nature 328:313-318.

Tang S, Mikala G, Bahinski A, Yatani A, Varadi G, Schwartz A (1993) Molecular localization of ion selectivity sites within the pore of a human L-type cardiac calcium channel. J Biol Chem 268:1302613029.

Turner TJ, Adams MF, Dunlap K (1992) Calcium channels coupled to glutamate release identified by $\omega$-Aga-IVA. Science 258:310-313.

Uchitel OD, Protti DA, Sanchez V, Cherksey BD, Sigimori M, Llinás $R$ (1992) P-type voltage-dependent calcium channel mediates presynaptic calcium influx and transmitter release in mammalian synapses. Proc Natl Acad Sci USA 89:3330-3333.

Usowicz MM, Sugimori M, Cherksey B, Llinás R (1992) P-lype calcium channels in the somata and dendrites of adult cerebellar purkinje cells. Neuron 9:1185-1199.

Viglione MP, Kim YI (1993) Lambert-Eaton syndrome serum inhibits P-type calcium channels in small-cell lung cancer cells. Soc Neurosci Abstr 19:703.

Viglione MP, Blandino JKW, Kim SJ, Kim YI (1993) Effects of Lambert-Eaton syndrome serum and IgG on calcium and sodium currents in small-cell lung cancer cells. Ann NY Acad Sci USA 681:418-421.

Vincent A, Lang B, Newsom-Davis J (1989) Autoimmunity to the voltage-gated calcium channel underlies the Lambert-Eaton myasthenic syndrome, a paraneoplastic disorder. Trends Neurosci 12:496502.

Williams ME, Burst PF, Feldman DH, Patthi S, Simerson S, Maroufi A, McCue AF, Velicelebi G, Ellis SB, Harpold MM (1992) Structure and functional expression of an $\omega$-conotoxin-sensitive human $\mathrm{N}$-type calcium channel. Science 257:389-395.

Yellen G, Jurman ME, Abramson T, MacKinnon R (1991) Mutations affecting internal TEA blockage identify the probable pore-forming region of a K+ channel. Science 251:939-941. 